\title{
THE LATENT CAUSES OF REWORK IN FLOATING PRODUCTION STORAGE AND OFFLOADING PROJECTS
}

\author{
Peter E. D. LOVEª, David John EDWARDS ${ }^{\mathrm{b}}$, Zahir IRANI ${ }^{\mathrm{c}}$, Nuria FORCADA ${ }^{\mathrm{d}}$ \\ ${ }^{a}$ School of Mechanical and Civil Engineering, Curtin University, GPO Box U9187 Perth, WA 6845, Australia \\ ${ }^{b}$ Birmingham City University, Business School, Galton Building, City North Campus, Perry Barr, \\ Birmingham, B42 2SU, UK \\ ${ }^{c}$ Business School, Brunel University, Uxbridge, Middlesex UB8 3PH, UK \\ ${ }^{d}$ Department of Construction Engineering, Universitat Politècnica de Catalunya, Barcelona, Spain
}

Received 16 May 2012; accepted 04 Sep 2012

\begin{abstract}
There is growing demand for cost effective and reliable floating production systems to maximize marginal and new deepwater fields worldwide. Floating Production Storage and Offloading (FPSO) vessels are considered to be the most economical and viable options to meet this demand. Yet, FPSO projects are prone to significant cost and schedule growth. On average, FPSOs have been reported to experience a $20 \%$ cost growth and are delayed by six months. Overruns and delays represent uncertainties for owners, contractors and financial institutions. In-depth interviews with twenty-three practitioners about their experiences with FPSO projects revealed that rework arising from design and construction errors were major contributors to cost and schedule growth. Key latent conditions contributing to rework are classified according to people, organization and project. Using retrospective sensemaking an examination of the determinant histories in a new build and conversion FPSO that experienced rework was undertaken. The sharing of experience(s) is deemed pivotal for reducing rework in future projects, particularly through the use of communities of practice that are able to stimulate situated learning to take place. A reduction in rework will not only reduce cost and schedule growth, improve operational performance and augment safety.
\end{abstract}

Keywords: conversion, errors, FPSO, learning, rework, new build, retrospection, sensemaking.

Reference to this paper should be made as follows: Love, P. E. D.; Edwards, D. J.; Irani, Z.; Forcada, N. 2014. The latent causes of rework in floating production storage and offloading projects, Journal of Civil Engineering and Management 20(3): 315-329. http://dx.doi.org/10.3846/13923730.2013.802725

\section{Introduction}

Floating Production Storage and Offloading (FPSO) vessels are a preferred system of choice for marginal, fasttrack or deepwater oil and gas field developments worldwide (Hardie, Knowles 2000; Lombardo 2003). Pressures to maximize marginal and new deep-water fields, particularly as a result of expanding subsea production technologies, have increased the demand for FPSOs. Logistical schedules for FPSO design, engineering, construction (or conversion) and installation have become increasingly over-stretched (Harris et al. 2004; Love et al. 2011a). Many of these developments have experienced significant cost and schedule growth as a result of complex commercial arrangements, project management and design/operating problems (Merrow 2003a, b; Eriksen 2010). A well-known example is the Terra Nova FPSO off the coast of Newfoundland in Canada, which experienced multi-year and multibillion-dollar overruns (House 2002; Brown 2004). On average, FPSOs experience a $20 \%$ cost growth and are delayed by six months (Fuglerud 2010). These aforementioned overruns and delays generate uncertainties for owners, contractors and finan- cial institutions (House 2002; Brown 2004). Frequently occurring factors that contribute to cost and schedule growth are (Hardie, Knowles 2000; Performance Forum 2000; Le Cotty 2003; Brown 2004; Shin et al. 2008; Erikson 2010; Fuglerud 2010):

- poor project scope definition;

-optimistic scheduling of design, engineering and construction;

-the placing of orders before engineering is completed;

- the implementation of new technology without qualification or justification;

-insufficient operational robustness and maintainability of engineering;

- logistical problems with component deliveries and documentation when transferring to fabrication processes;

- fabrication yards having to build competence and resources during the project; and

- poor interface management between contractual parties. 
To meet a project's scheduled completion date, activities are often undertaken concurrently. By exceeding the limits of concurrency, complexity and the probability of activity delay increases particularly when revisions, repairs and rework occur (Friedrich et al. 1987; McConnell 1999). Schedule pressure provides a fertile environment for error propagation but also reduces the likelihood of error detection using standard procedures (Love et al. 2009). Design errors deemed to be minor in nature are often overlooked or dismissed due to the time that it would typically take to correct them (Paté-Cornell 1990). An 'escalation to commitment' may prevail if any ambiguities are identified which may "invalidate efforts of the initial design and engineering that has been undertaken" (Paté-Cornell 1990: 1214). Prevailing uncertainty surrounding offshore projects creates problematic planning, particularly when information is unavailable. Under such adverse circumstances, there is an overreliance on scope changes to resolve problems arising during construction, installation and commissioning.

Despite considerable advancements in the ability to reduce and predict the likelihood of human and organisational errors within the offshore industry (Ren et al. 2008; Saleh et al. 2010; Nam et al. 2011), they still occur in FPSOs; therefore, necessitating costly rework (Hardie, Knowles 2000; Vinnem 2000; Lloyd's Register 2003; Love et al. 2011a). Human errors in design, fabrication and operation cause most, if not all serious accidents (Moan et al. 2002). Error driven rework can contribute to FPSO performance failures, especially if during the facility's operation, a complete shutdown of production or withdrawal of other services is needed (Llewellyn et al. 2002).

In this paper, in-depth interviews with practitioners were undertaken to determine the latent conditions that contribute to rework within FPSO projects. The research is exploratory in nature and is the first attempt to examine rework in FPSOs. Thus, retrospective sensemaking is used to identify the general factors contributing to rework as well as the determinant histories for a new build and conversion FPSO that experienced this phenomenon. This followed by a discussion that suggests learning from experience, specifically through the establishment of communities of practice ( $\mathrm{CoP})$, can contribute to reducing and containing rework in future projects.

\section{Floating storage production and offloading vessels}

FPSO vessels are amongst an array of floating systems used to process and store hydrocarbons extracted from subsea fields (Figs 1 and 2). They can replace fixed production platforms and pipeline systems which extract oil and gas from shallower fields or those that are not technically or commercially viable for smaller, deepwater applications. Additionally, they can receive oil produced from nearby platforms or subsea and process and store it in readiness for tanker offloading or pipeline transportation (Lombardo 2003). New build FPSOs or tanker conversion variants which use an existing hull, can be towed and permanently fixed to an offshore reservoir to form a 'hub', which is connected to seabed wells via flexible risers (Lombardo 2003). A cylindrical hull FPSO is a relatively recent innovation developed by Sevan Marine and Siemens Oil \& Gas. A prominent cylindrical FPSO is the Sevan Hummingbird, which is currently operating in the North Sea (Fig. 2).

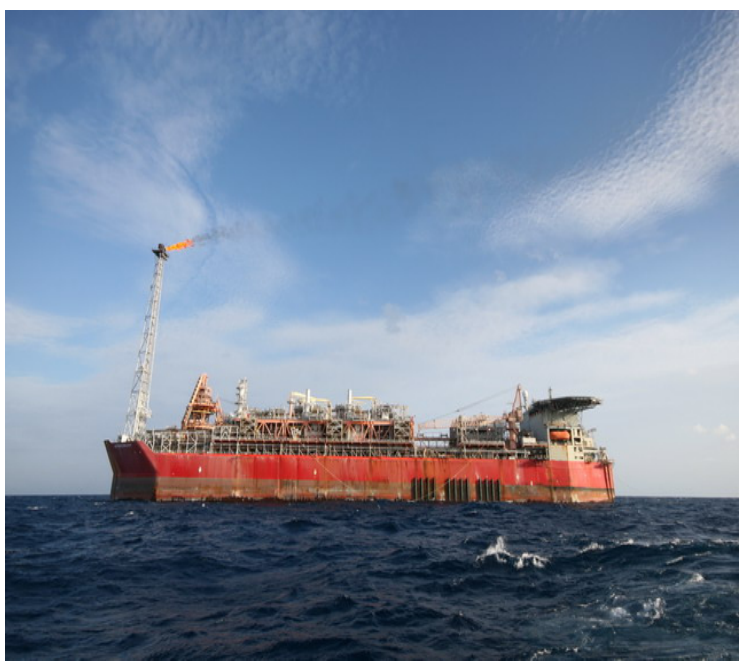

Fig. 1. FPSO Northern Endeavour

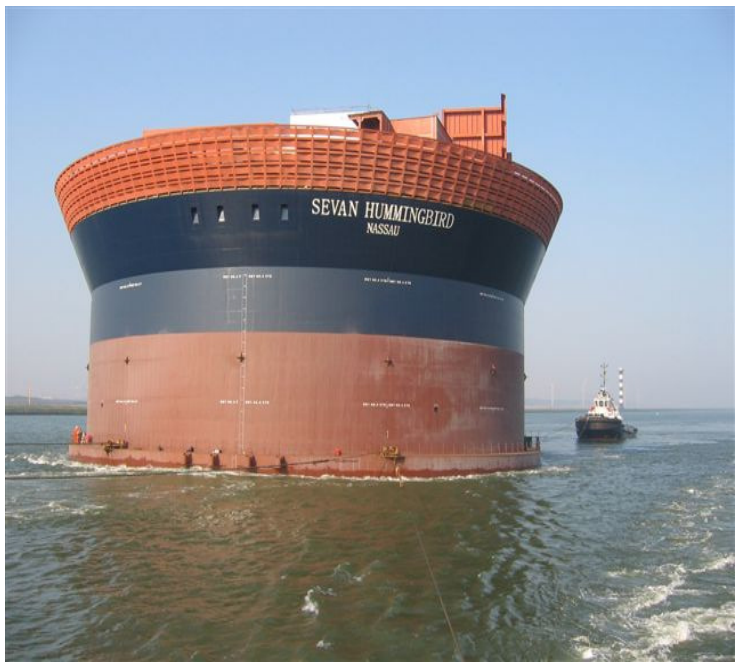

Fig. 2. FPSO Sevan Hummingbird

A turret mooring system used enables an FPSO to 'weathervane' through 360 degrees. This type of mooring effectively ensures that the vessel's bow is kept pointing into the prevailing wind and currents, thereby minimizing the impact of severe inclement conditions. Often, thruster systems used aid station-keeping and to control the vessel's heading. Anchor wires, flexible risers and control umbilical's from the seabed all reach the surface through the turret. External turret moorings, mounted at either the FPSOs bow or stern, can provide an adequate mooring system for moderate environments.

FPSOs are typically preferred in frontier offshore regions because they do not require a pipeline infrastructure to export oil which makes installation easier, and Capital Expenditure (CAPEX) and Operational Expenditure (OPEX) lower. In turn, these efficiency measures translate into quicker revenue generation and renewed investment and development in the field. 
Table 1. Advantaged and disadvantages of FPSOs

\begin{tabular}{|c|c|}
\hline Advantages & Disadvantages \\
\hline $\begin{array}{l}\text { Early deployment: Can be deployed while the field is } \\
\text { being developed. Cash flow is increased which enables } \\
\text { greater investment in the field. }\end{array}$ & $\begin{array}{l}\text { High cost of risers: The price of a riser system connected to an } \\
\text { FPSO is generally higher than the steel catenary risers used in } \\
\text { conjunction with tension leg and spar platforms. }\end{array}$ \\
\hline $\begin{array}{l}\text { Multi-functional usage: Can be used in conjunction with } \\
\text { other offshore facilities and utilized in more than one field. } \\
\text { The extensive deck area offers flexibility. }\end{array}$ & No well access: Lacks access to wells and drilling equipment. \\
\hline $\begin{array}{l}\text { Field storage: Self-contained and possesses segregated } \\
\text { storage and is therefore independent of any existing struc- } \\
\text { ture. Can be situated in fields that are distant from existing } \\
\text { facilities. Shuttle tankers can transport oil and gas to on- } \\
\text { shore facilities. }\end{array}$ & $\begin{array}{l}\text { High well maintenance: The subsea tiebacks associated with } \\
\text { FPSOs generally bring about higher well maintenance costs. }\end{array}$ \\
\hline $\begin{array}{l}\text { Disconnection: Depending on specifications and the time } \\
\text { necessary, are able to disconnect within } 24 \text { hours if } \\
\text { planned. }\end{array}$ & $\begin{array}{l}\text { Limited number of risers: All risers must pass through the turret } \\
\text { bearing. The size of the bearing governs the number of risers that } \\
\text { can pass within the turret. The production rate that can be obtained } \\
\text { from a field is limited. }\end{array}$ \\
\hline $\begin{array}{l}\text { Adaptive to water depths: Operate in depths of water } \\
\text { ranging from } 20 \text { to } 1800 \mathrm{~m} \text {. The FPSO operating in the } \\
\text { deepest water depth is the Espirito Santo FPSO from Shell } \\
\text { America operated by Brazilian Deepwater Production Ltd. } \\
\text { The FPSO is moored at a depth of } 1,800 \mathrm{~m} \text { in the Campos } \\
\text { Basin, Brazil. The Kizomba A FPSO (was the world's } \\
\text { largest at the time of construction), with a storage capacity } \\
\text { of } 2.2 \text { million barrels }\left(350,000 \mathrm{~m}^{3}\right) \text {. The cost of a FPSO } \\
\text { mooring in deep water is more economical than that of } \\
\text { fixed structures or tension leg platforms }\end{array}$ & $\begin{array}{l}\text { Movement and motion: Motions are too excessive to support 'dry' } \\
\text { trees in typical applications and which require a turret mooring } \\
\text { system for most environments. The turret mooring system allows } \\
\text { the FPSO to weathervane around an earth-fixed mooring so that the } \\
\text { vessel is in the most favourable orientation relative to wind, waves } \\
\text { and current. The turret mooring system works best in environments } \\
\text { where wind, waves and current are typically aligned (Lopez-Cortijo } \\
\text { et al. 2003). }\end{array}$ \\
\hline $\begin{array}{l}\text { Early leasing: An FPSO can be leased up-front, which can } \\
\text { reduce CAPEX costs and risks for the oil company. The } \\
\text { use of early leasing can also enable a field to be developed } \\
\text { quickly (Hardie, Knowles 2000). }\end{array}$ & $\begin{array}{l}\text { Accommodation: Limited space for accommodation, especially for } \\
\text { those who are required to take operational maintenance. Motion } \\
\text { sickness for those undertaking repairs can be a problematic issue } \\
\text { (Llewellyn et al. 2002). }\end{array}$ \\
\hline $\begin{array}{l}\text { Extended well testing: Enable well testing to span across } \\
\text { longer periods of time and thereby enhance reservoir in- } \\
\text { formation. }\end{array}$ & $\begin{array}{l}\text { Potential for collision: Risk of collision with supply vessels, shut- } \\
\text { tle tankers and passing ships. A collision accident can lead to costly } \\
\text { consequences in loss of lives, damage to property and/or environ- } \\
\text { ment (Moan et al. 2002; Wang et al. 2003). }\end{array}$ \\
\hline $\begin{array}{l}\text { Less weight sensitive: Less weight sensitive and can } \\
\text { therefore be used in different fields with varying produc- } \\
\text { tion capacities. Production volumes can range. }\end{array}$ & $\begin{array}{l}\text { Interface management: Increased number of interfaces required } \\
\text { for delivering an FPSO which include: topsides, hull, turret, moor- } \\
\text { ing, risers and offshore (installation, mooring, riser, hook-up, com- } \\
\text { missioning) (Shin et al. 2008). }\end{array}$ \\
\hline $\begin{array}{l}\text { Ecological and economic: The price of an aging tanker or } \\
\text { bulk vessel to be converted into an FPSO is cheaper than a } \\
\text { new build. The re-use of existing marine stock leads to a } \\
\text { better utilization of ecological and economic resources } \\
\text { (Hardie, Knowles 2000). }\end{array}$ & $\begin{array}{l}\text { Early leasing: The traditional operator is replaced by a 'duty hold- } \\
\text { er' and the oil company's project team by a skeleton project man- } \\
\text { agement group (Hardie, Knowles 2000). Experience in design and } \\
\text { operations, and a technical overview of the development are lost. } \\
\text { Fast tracking of design generally leaves limited time for FEED. }\end{array}$ \\
\hline $\begin{array}{l}\text { Safety: FPSOs have demonstrated to be safer in terms of } \\
\text { their accident records than fixed platform offshore struc- } \\
\text { tures. Two major accidents that arose without loss of life, } \\
\text { were on the Lan Shui FPSO in 1990, and Uige FPSO in } \\
1999 \text { (Vinnem 2000). }\end{array}$ & $\begin{array}{l}\text { Maintenance and repairs: Inadequate design of turret, hoses, } \\
\text { production separators, set chests and hull can lead to significant } \\
\text { repairs being undertaken (Lloyds Register 2003). Production and } \\
\text { profit losses can arise if an FPSO is out-of-service, especially if } \\
\text { repairs are required in a shipyard. }\end{array}$ \\
\hline
\end{tabular}

\subsection{FPSO project delivery}

The design, development and implementation of an FPSO is technically challenging and complex. Hydrocarbon reservoirs, for example, can vary with geographical locations and field characteristics. No two crudes are identical, although basic oil classifications (e.g. black oils, condensate, sweet, sour) can dictate topside processing options (Mueller, Roobaert 2008). In addition to slight differences in the oil's properties, other factors such as payloads, metocean characteristics and mooring patterns often impact upon topside design. An FPSO project typically interfaces with the Subsea production System's Umbilical, Risers and Flowlines (SURF), topsides, vessel and possibly a pipeline. A high degree of differentiation and interdependency exists between each of the aforementioned elements (Hardie, Knowles 2000). A number of different contractors may supply the FPSO vessel's major components, for example, the shipyard, mooring system contractor and process unit manufacturer (Alford 1997).

Turnkey contract strategies or hybrids thereof, form the cornerstone of FPSO projects (Alford 1997; Hardie, Knowles 2000; Harris et al. 2004; Berends 2007; Cecil 2008). Such contracts provide single point responsibility, fixed contract price and completion date. The contractor is therefore responsible for all design and engineering (encompassing detailed design, Front End Engineering 
Design (FEED) and detailing engineering), procurement, construction (hull), commissioning and testing activities. An alternative delivery approach is a 'Modular Strategy' where the oil company forms separate contracts for different component parts of the project such as the design, procurement, construction and installation. The oil company may also manage the FPSO's marine and offshore operations although Cecil (2008) contends that this is very rare considering the project's scale, complexity and associated risks involved. To mitigate risk, alliance contracting is used by many oil companies who seek to share responsibilities with contractors and jointly improve field development economics. Drawing upon design and construction experiences stemming from the Schiehallion FPSO (North West Atlantic), Green (1999) suggests that there is no 'one best way' to execute a project because each bespoke mix of technology and contractors is affected by different drivers.

\section{Rework: latent conditions and active failures}

Rework has been defined as "the unnecessary effort of redoing a process or task that was incorrectly implemented the first time" (Love 2002). On construction and engineering projects rework is a dogged issue and major contributor to cost and schedule growth (Love 2002; Hwang et al. 2009). On average, rework contributes to $52 \%$ of a total cost overrun incurred, increase schedule by $22 \%$ and range in cost from 5 to $20 \%$ of contract value in construction and engineering projects (Love 2002). Within oil and gas projects, however, there is limited knowledge about the causes and costs of rework. This is surprising considering that one in eight major offshore developments (with a CAPEX ranging from US $\$ 1$ billion to US $\$ 3$ billion) are deemed to be a financial disaster (Merrow 2003a).

Within construction and engineering projects, rework has been attributed to latent conditions that reside within the organizational and project systems (Love et al. 2009). Reason (1997) states that "latent conditions are to technological organizations what resident pathogens are to the human body". At an organizational level, this may manifest as insufficient training, inadequate resourcing levels and a poor quality management focus. At a project level, lack of supervision, competitive tendering and contracting strategy have provided fertile conditions for errors to propagate (Love et al. 2011a). Latent conditions lay dormant within a system until an error comes to light but they arise because of strategic decisions taken by senior management, government, regulators, designers and key decision-makers (Roberts, Bea 2001). The ramifications of these decisions spread throughout an organization and project, shaping culture and creating errorproducing factors within individual workplaces (Reason 1997). Latent conditions or 'pathogens' are defined by a number of qualities; namely (Busby, Hughes 2004):

- they are a relatively stable phenomena that have been in existence for a substantial time before the dispute occurs;

- before the dispute occurs, they would not have been seen as obvious stages in an identifiable sequence failure; and -they are strongly connected to the dispute, and are identifiable as principal causes of the disputes once it occurred.

According to Busby and Hughes (2004) pathogens can be categorized as:

- Practice - arising from people's deliberate practices;

- Task - arising from the nature of the task being performed;

- Circumstance - arising from the situation or environment that the project was operating in;

- Convention - arising from standards and/or routines;

- Organization - arising from organizational structure or operation;

- System - arising from an organizational system poorly designed processes;

- Industry - arising from the structural property of the industry; and

- Tool - arising from the tool's technical characteristic.

Active failures are unsafe acts committed by people who are in direct contact with a system. They are characterised as being elusive and often difficult to foresee but importantly, they cannot be eliminated by reacting to the event. Latent conditions and active failures combined engender significant error consequences (Reason 1990). For example, in the case of Occidental Petroleum's Piper Alpha platform collapse in the UK, which occurred in 1988 and killed 167 workers, the following incident compromising of several active failures would be impossible to predict:

"Workers shut down a pipeline to remove a defective pump, and then went off duty before finishing the job. They had placed a cap on the pipe when the pump was removed but the workers failed to tighten the bolts thinking that the pipe would remain out of service until the new pump was installed. Somehow, the paperwork never reached the controller who came on duty with the new shift. He pressurized the pipeline not knowing about the temporary cap and pump replacement work in progress, which resulted in a major gas leak, and resulting explosion - destroying the platform" (Diekmann 2010).

These active failures have an immediate impact and are committed at the human-system interface (Reason 1997). The presence of latent conditions increase the likelihood that active failures will occur by generating local factors that promote an individual to commit an error or violation (Reason 1990, 1997).

Errors can take the form of slips, lapses, mistakes and violations - cf. Figure 3 (Reason 1990). Violations constitute aberrant behaviour and are analogous to omission errors, although an error may not necessarily be propagated. Violations are necessary deliberate deviations from standard practices (Reason 1990). Before errors become apparent, participants often remain unaware that particular decisions, practices or procedures can have a dramatic impact upon project performance (Busby, Hughes 2004; Love et al. 2009). Unidentified errors remain in a perpetual state of incubation and become 


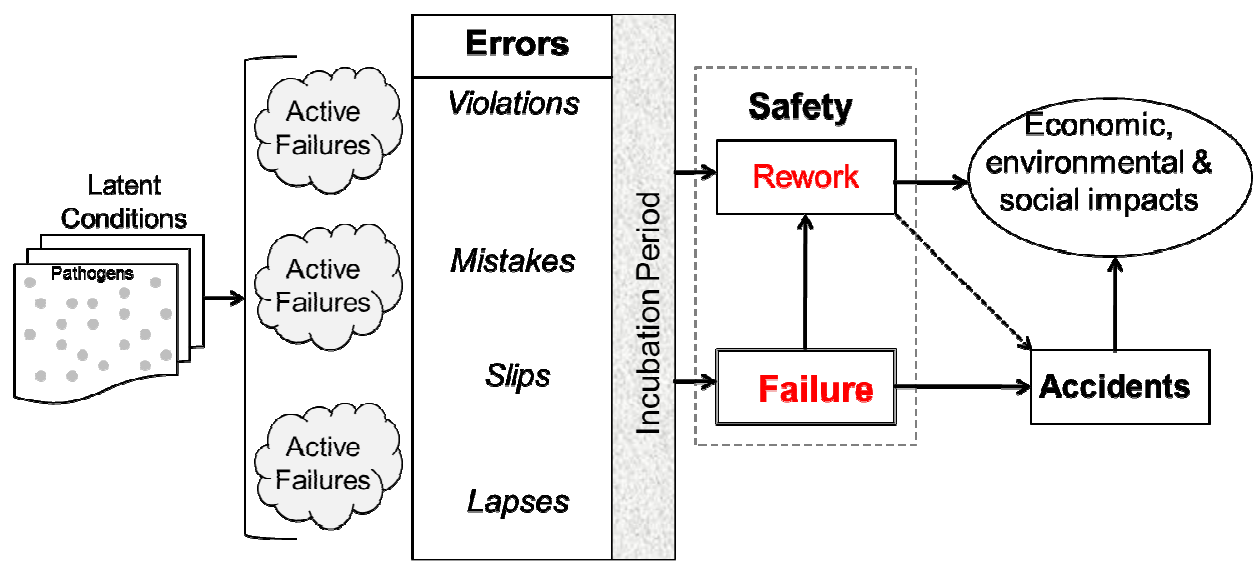

Fig. 3. Latent conditions, errors and rework (Love, Edwards 2013)

an integral part of everyday work practices; upon identification, rework can commence. Design and construction errors that arise during FPSO maintenance and inspection represent the most significant and expensive failures (Llewellyn et al. 2002; Lloyd's Register 2003; Marin, Garcia 2003; Biasotto, Rouhan 2004). Reported examples of design errors include (Lloyds Register 2003):

- bow - inadequate structural design and consideration of environmental loadings;

- breakdown of coating systems - poor selection and application; and

- tank - inadequate construction techniques.

For example, inspection of ballast, cargo tanks and propeller shafts involves the mobilization of inspection teams which is both costly and timely. As FPSOs generally remain on site during the life of the field without being disconnected or removed from their mooring system, dry docking is not considered to be a viable economic option. Therefore, inspections and repairs must be performed on-site and under continuous operation. If schedule or production pressure becomes a problem during error rectification, then safety could potentially be compromised and accidents occur (Love et al. 2004; Goh et al. 2012).

\section{Research methodology}

To determine the causal nature of rework in FPSO projects, the ontology of 'subjective idealism' was adopted because of the limited discourse in this specific field of research (Farrell 1996). For this approach, subjects construct their own views and opinions on the phenomena under investigation based upon their experiences; an inclination to truth and pragmatism is deemed to prevail. Sensemaking is used to underpin the ontology adopted, as meaning is given to experience, dialogue and narratives about events that have occurred through a process of retrospection (Weick 1988, 1995). The notion of 'retrospective sensemaking' is derived from Schutz's (1967) analysis of 'meaningful experience' where events occur in a moment of time and can exist in pure duration and as discrete segments (Hartshorne 1962; Schutz 1967). Pure duration can be described as a "stream of experience" (James 1950, cited in Weick 1995). Experience is a sin- gular construct and is a "coming-to-be and passing-away that has no contours, no boundaries and no differentiation" (Schutz 1967, cited in Weick 1995).

Experiences, however, imply distinct, separate episodes (Weick 1995). The creation of meaning from experience(s) is reliant upon a temporal process of attention being directed backward from specific periods in time; so whatever presently occurs will influence future discoveries when people analyse the past (Bantz, Smith 1977; Weick 1995; Brown 2000; Weick et al. 2005). Furthermore, memories are events that occur in a given period of time, so anything that affects a person's ability to remember will also affect the same sense that is made of those memories. With this in mind, Fischoff (1975) states that 'creep determinism' can prevail, especially "when people already know the outcome of a complex prior history as being much determinant" (Weick 1995). Consequently, the nature of determinant histories can be reconstructed differently (Weick 1995) and is akin to a post modernistic view as one person may experience the same phenomenon differently from another (Alvesson, Deetz 1996; Kim 2002; Love et al. 2002). For example, if an outcome is perceived to be bad, then antecedents are reconstructed to emphasise incorrect actions and inaccurate perceptions even if they were not influential or obvious at the time (Bantz, Smith 1977; Weick 1995). In this instance, retrospective sensemaking implies that errors should be anticipated and reduced through a process of 'good project management'. The future is indeterminate, and the past is reconstructed knowing the outcome, thus past events are rarely recalled exactly as they happened. Reason (1990) asserts that the "knowledge of the outcome of a previous event increases the perceived likelihood of that outcome" which can lead people to overestimate their ability to influence future events. This phenomenon is known as the 'illusion of control' (Langer 1975). Organizations with a strong desire and willingness to reduce errors within FPSO projects, require an interpretation of past indeterminacy that favours order and oversimplifies causality (Reason 1990). This approach facilitates a meaningful context as to 'why' and 'how' errors occurred to materialise, which provide valuable insights that help construct lessons for the future. 


\subsection{Data collection}

Interviews are an effective tool for learning about matters that cannot readily be observed (Kvale 1996) and were therefore utilised as the primary data collection mechanism. Over a four month period, twenty-three in-depth interviews were conducted with a variety of personnel including operations managers (3), project managers (10), structural engineers (3), procurement managers (2), mechanical managers (2) and engineering managers (3). The research team had a direct contact point within the participating organization that had an interest in understanding 'why' and 'how' rework emerged in projects. For reasons of commercial and individual confidentially, specific details about the organization are not presented. The organisation's procurement personnel were invited to participate in the research and interviews were conducted at the offices of interviewees for their convenience. Interviews were digitally recorded and subsequently transcribed verbatim to allow for finer nuances of the interview to be documented. Hand written notes were also taken during the interview to maintain validity. The interviewees' details were coded to preserve anonymity, although all interviewees were aware that their identities might be revealed from the textural narrative. The interview format was kept as consistent as possible following the emergent themes associated with rework identified from the extant literature.

The interview commenced by asking individuals about their experience within industry, and their current role within the organisation ${ }^{1}$. Interviewees were then invited to select a completed project they had been involved with, identify a particular rework incident that had taken place and explain how and why it arose. Phrases such as 'tell me about it' or 'can you give me an example' were asked at opportune moments when further information was required. These open questions allowed for avenues of interest to be pursued because they arose without introducing bias in the response. Interviewees were asked to identify the principal sources of rework that occurred in offshore projects and suggest strategies that could be used to prevent future reoccurrence. Interviews varied in length from one to three hours and sought to stimulate conversation whilst simultaneously breaking down any interpersonal barriers that may have existed between the interviewer and interviewee. A copy of each interview transcript was given to each interviewee for comment to check overall validity and accuracy. In conjunction with the interviews, documentary sources for each project discussed were provided.

\subsection{Data analysis}

The text derived from the interviews was analysed using QSR N5 which is a version of NUD*IST and combines the efficient management of non-numerical unstructured data with powerful processes of indexing and theorizing. QSR N5 enabled additional data sources and journal notes to be incorporated into the analysis as well as iden-

\footnotetext{
${ }^{1}$ A copy of the research instrument used for the interviews can be obtained on request from the corresponding author.
}

tify new emergent themes. The development and reassessment of themes as analysis progresses accords with the calls for avoiding confining data to pre-determined sets of categories. Kvale (1996) suggests that ad hoc methods for generating meaning enable the researcher to access "a variety of common-sense approaches to interview text using an interplay of techniques such as noting patterns, seeing plausibility, making comparisons, etc.”. Using QSR N5 facilitated an organic approach to coding because it enabled triggers or categories of textural interest to be coded and used to monitor emerging and developing ideas (Kvale 1996). These codings can be modified, integrated or migrated as the analysis progresses and the generation of reports, using Boolean search, facilitates the recognition of conflicts and contradictions.

\section{Sensemaking of rework in FPSOs: an exploration of experience(s)}

The analysis of the research findings commences with an overview of the interviewees experiences with rework in FPSO projects under the nomenclatures of project, organization and people (POP). Then two specific FPSO projects that experienced significant rework are examined in detail.

Each interviewee provided intuitive estimates of rework costs for FPSO projects. These ranged from $10 \%$ to $25 \%$ of CAPEX. If an Engineering Procurement and Contract (EPC) contract strategy was used, a 10\% cost growth, with $5 \%$ due to rework was deemed to be acceptable considering the uncertainty and complexity associated with FPSOs. When considering the potential for introducing optimism bias (i.e. over estimating the likelihood of positive events and conversely underestimating the likelihood of negative events), the actual rework costs could be considerably higher.

Cost growth was deemed to be a norm within FPSO projects. Having to undertake rework as a result of errors and omissions was an issue not formally recognized during FEED within the previous organizations, where interviewees had been employed. Even though post mortems from completed projects were used as a formalized learning mechanism for future projects, the inclusion of any form of risk assessment or even acknowledgment of rework was eschewed: it is a 'taboo' and its costs are buried within a project's contingency sum. To the interviewees rework was not measured; it existed and occurred regularly, but was concealed deep within an organization's subconsciousness until a major incident arose.

Industry's unwillingness to admit rework being a problem was made blatantly apparent by a senior project manager who had over 15 years' experience working in offshore environments who initially stated: “...we don't have rework in our projects". This shielding comment portrayed officialdom within the organisation they were representing vis-à-vis the individual's personal thoughts. The mere recognition that errors occurred could potentially jeopardize the organisation's corporate image and possibly share value. As the interview unfolded, the sincere and reflective voice and experience of the individual surfaced and it was clear that rework was indeed a costly and recurrent issue on many of the organisation's projects. 
If rework costs of 5\% of CAPEX are an acceptable norm, there is a danger that this 'norm' will insidiously creep up further and settle in at an uncomfortable level, particularly as demand for energy and hydrocarbons increases. Repeated occurrence of rework within offshore projects creates complacency and nurtures a culture of it being a necessary evil of doing business. The percentage increase in rework undoubtedly adds to an organisation's overall costs. If rework accounts for $5 \%$ of an organisation's regular work, this would lead to costs across the board being increased by $5 \%$ : i.e. supervision, cycle time for administrative procedures, answering requests for information and so on. The time element obviously translates into costs, which are then buried in what would be considered 'normal' operating costs. History suggests that those who fail to learn from their mistakes are invariably condemned to relive them again. Insight gained from previous project(s) mistakes or oversights can be gainfully employed in preventing future repetition. Learning from mistakes is difficult but continuing to make the same ones is far harder and certainly more costly.

\subsection{Rework causation: experiences from the field}

Table 2 identifies the factors contributing to rework in FPSO projects emanating from interviewee experiences. The number of times interviewees referred to factors is also identified, with the most common being denoted in Table 2 in bold. Specific examples of errors identified included inflexible pipework design, insufficient gas compression capacity, inadequate isolation valves and leakages in the swivel. Many of factors identified in Table 2 are interdependent and, therefore, are unable to be considered as singular contributors to rework. With this in mind, it is necessary to determine the pathogens that influence these factors; these were derived from the dialogue and narratives that transpired and provided a meaning and context for rework experiences.

The push for 'early production' to capitalize on crude prices was categorized as a pathogen of 'circumstance'. However this behaviour was perceived to establish 'organizational impairment' whereby actions within

Table 2. Perceived project, organization, and people factors influencing rework from acquired experiences

\begin{tabular}{|c|c|c|c|c|c|c|c|c|}
\hline Project & 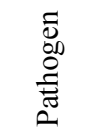 & $\mathrm{N}$ & Organization & 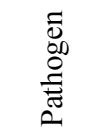 & $\mathrm{N}$ & People & 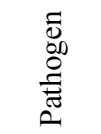 & $\mathrm{N}$ \\
\hline $\begin{array}{l}\text { Inappropriately designed } \\
\text { Heating Ventilation Air Con- } \\
\text { ditioning (HVAC) systems }\end{array}$ & $\mathrm{T}$ & 4 & $\begin{array}{l}\text { Inadequate matching of } \\
\text { individual to task }\end{array}$ & $\mathrm{O}, \mathrm{C}, \mathrm{T}$ & 3 & $\begin{array}{l}\text { Stress (e.g. due to } \\
\text { work overload) }\end{array}$ & $\mathbf{O , C}$ & 11 \\
\hline $\begin{array}{l}\text { Hydro-carbon reservoir simu- } \\
\text { lations were incomplete }\end{array}$ & $\mathrm{C}, \mathrm{T}, \mathrm{P}$ & 9 & $\begin{array}{l}\text { Insufficient design audits, } \\
\text { reviews and verifications }\end{array}$ & $\mathrm{T}, \mathrm{P}$ & 7 & $\begin{array}{l}\text { Lack of expertise } \\
\text { and experience }\end{array}$ & $\mathrm{C}, \mathrm{O}$ & 7 \\
\hline $\begin{array}{l}\text { Uncertainty associated with } \\
\text { the behavior of the hydrocar- } \\
\text { bon reservoir }\end{array}$ & $\mathrm{C}, \mathrm{T}, \mathrm{P}$ & 9 & Inadequate training & $\mathrm{O}, \mathrm{C}, \mathrm{T}$ & 5 & Omission of checks & T,P & 11 \\
\hline Inadequate scope definition & $\mathrm{C}, \mathrm{T}, \mathrm{P}$ & 14 & Staff continuity & $\mathrm{O}, \mathrm{C}, \mathrm{T}$ & 3 & $\begin{array}{l}\text { Distribution of } \\
\text { wrong information }\end{array}$ & $\mathrm{T}, \mathrm{P}, \mathrm{O}$ & 7 \\
\hline $\begin{array}{l}\text { Pressure to commence } \\
\text { production }\end{array}$ & $\mathrm{C}, \mathrm{I}$ & 18 & $\begin{array}{l}\text { Over reliance on } 3-\mathrm{D} \\
\text { CAD }\end{array}$ & $\mathrm{O}, \mathrm{TO}$ & 5 & $\begin{array}{l}\text { Misinterpretation } \\
\text { due to lack of } \\
\text { knowledge }\end{array}$ & $\mathrm{C}, \mathrm{O}, \mathrm{T}$ & 5 \\
\hline $\begin{array}{l}\text { Commencement of construc- } \\
\text { tion of hull before engineer- } \\
\text { ing of topsides complete }\end{array}$ & T,P & 13 & $\begin{array}{l}\text { Distribution of tentative } \\
\text { engineering documents }\end{array}$ & $\begin{array}{l}\mathrm{C}, \mathrm{O} \\
\mathrm{T}, \mathrm{P}\end{array}$ & 10 & Long working hours & $\mathrm{C}, \mathrm{O}, \mathrm{I}$ & 9 \\
\hline $\begin{array}{l}\text { Inadequate interface man- } \\
\text { agement of engineering } \\
\text { consultants, contractors, } \\
\text { \& fabricators }\end{array}$ & $\begin{array}{l}\mathrm{CO} \\
\mathrm{C} \\
\mathrm{T}, \mathrm{P}\end{array}$ & 17 & $\begin{array}{l}\text { Inadequate skills and } \\
\text { knowledge of software }\end{array}$ & $\mathrm{C}, \mathrm{O}$ & 2 & & & \\
\hline $\begin{array}{l}\text { Lack of adherence to quality } \\
\text { controls and assurance during } \\
\text { construction }\end{array}$ & $P$ & 13 & $\begin{array}{l}\text { Unrealistic schedule to } \\
\text { complete tasks and } \\
\text { processes }\end{array}$ & $\mathrm{C}, \mathrm{I}, \mathrm{O}$ & 11 & & & \\
\hline Poor supervision & $\mathrm{O}, \mathrm{T}, \mathrm{P}$ & 13 & $\begin{array}{l}\text { Non-adherence to organi- } \\
\text { zational quality systems }\end{array}$ & $\mathrm{O}, \mathrm{T}, \mathrm{P}$ & 9 & & & \\
\hline $\begin{array}{l}\text { Limited support from the } \\
\text { structural engineer to the } \\
\text { electrical engineering contrac- } \\
\text { tor regarding design }\end{array}$ & $\mathrm{CO}, \mathrm{T}$, & 3 & Poor supervision of staff & & 5 & & & \\
\hline Weld contamination & $\mathrm{T}$ & 3 & $\begin{array}{l}\text { Lack of resourcing and } \\
\text { planning }\end{array}$ & $\mathrm{C}, \mathrm{O}$ & 7 & & & \\
\hline $\begin{array}{l}\text { Coating failures (e.g., leading } \\
\text { to corrosion) }\end{array}$ & $\begin{array}{l}\mathrm{CO}, \mathrm{T} \\
\mathrm{P}\end{array}$ & 5 & $\begin{array}{l}\text { Inadequate coordination } \\
\text { and integration with other } \\
\text { project team members }\end{array}$ & $\begin{array}{l}\mathrm{CO}, \mathrm{C} \\
\mathrm{O}\end{array}$ & 4 & & & \\
\hline $\begin{array}{l}\text { Misapplication of functional } \\
\text { specification }\end{array}$ & $\begin{array}{c}\mathrm{CO}, \mathrm{T}, \\
\mathrm{P}\end{array}$ & 3 & & & & & & \\
\hline
\end{tabular}

Key: Practice (P), Task (T), Circumstance (C), Convention (CO) Organization (O), System (S), Industry (I), Tool (TO). 
projects followed predetermined plans and practices, irrespective of lessons learnt from previous projects. For example, a proclivity to fast-track the conceptual design and FEED stage often lead to poor scope definition and change orders occurring.

A contingency sum for 'design change orders' was considered to be a solution for addressing problems that could materialize downstream during construction and fabrication. Despite being aware of potential changes, project managers choose not to alter their plans regardless of what ambiguity or uncertainty confronts them. Even though each project is bespoke, when decisions were required the most familiar plans and processes were adopted irrespective of whether they were good or bad (i.e. the passing of design responsibility from contractor to vendor for topsides to minimize risk). Underperforming projects that incurred rework, were often explained away as being an isolated instance of unfortunate circumstances and were not considered to be conventional practice; an outlier event. Despite this outlier status, explanations and justifications for the occurrence of rework, after the fact, were proffered to make the event appear explicable and predictable.

Fixed price contracts implemented within a competitive tendering process often resulted in contractors being awarded work at the lowest cost where margins for error are severely limited. When an error arises one of two outcomes results; either short-cuts are taken or work is not undertaken with a due level of diligence. Commercial constraints imposed upon an oil company and the contract strategy implemented reduces its ability to provide management input into a project, especially in the case of lease-type contracts, as they can be kept at 'arm's length' by the EPC contractor or vessel owner. Issues such as quality, interface management and resourcing may be abrogated. With a dearth of project management experience input throughout the EPC phases, the propensity for errors and rework increases.

From the experiences provided, the 'circumstances' associated with an FPSO project provided the impetus for other pathogens to materialize such as 'task' and 'practice' (Fig. 4). Under the nomenclature of organization (Table 2), 'non-adherence to quality systems' was identified as a 'task-related pathogen' that contributed to rework. It was revealed that short cuts were sometimes taken in order to complete tasks and issues that appeared to be purely administrative and were often over-looked. Fundamentally, people will break rules if they believe they can make work more efficient even when the reality may be very different.

A leitmotif among 'practice-related pathogens' was the poor and untimely communication of information between the parties involved with the delivery and installation of FPSOs. As a result of schedule, people's decisions were founded upon a trade-off between available information and time. Information provided under such adverse circumstances often lacked accuracy and currency, especially when a 'fast-track' approach was adopted. One engineering manager reflected upon a topside contractor who was provided with the wrong information for the turret configuration. Issues of interface management that arose oscillated between vessel and topside design, and topside/marine contractor and subsea. Inadequately integrated project team members and the exclusion of operations from key decision-making during the FEED were considered responsible for preventing feedback about errors on site being incorporated into future projects.

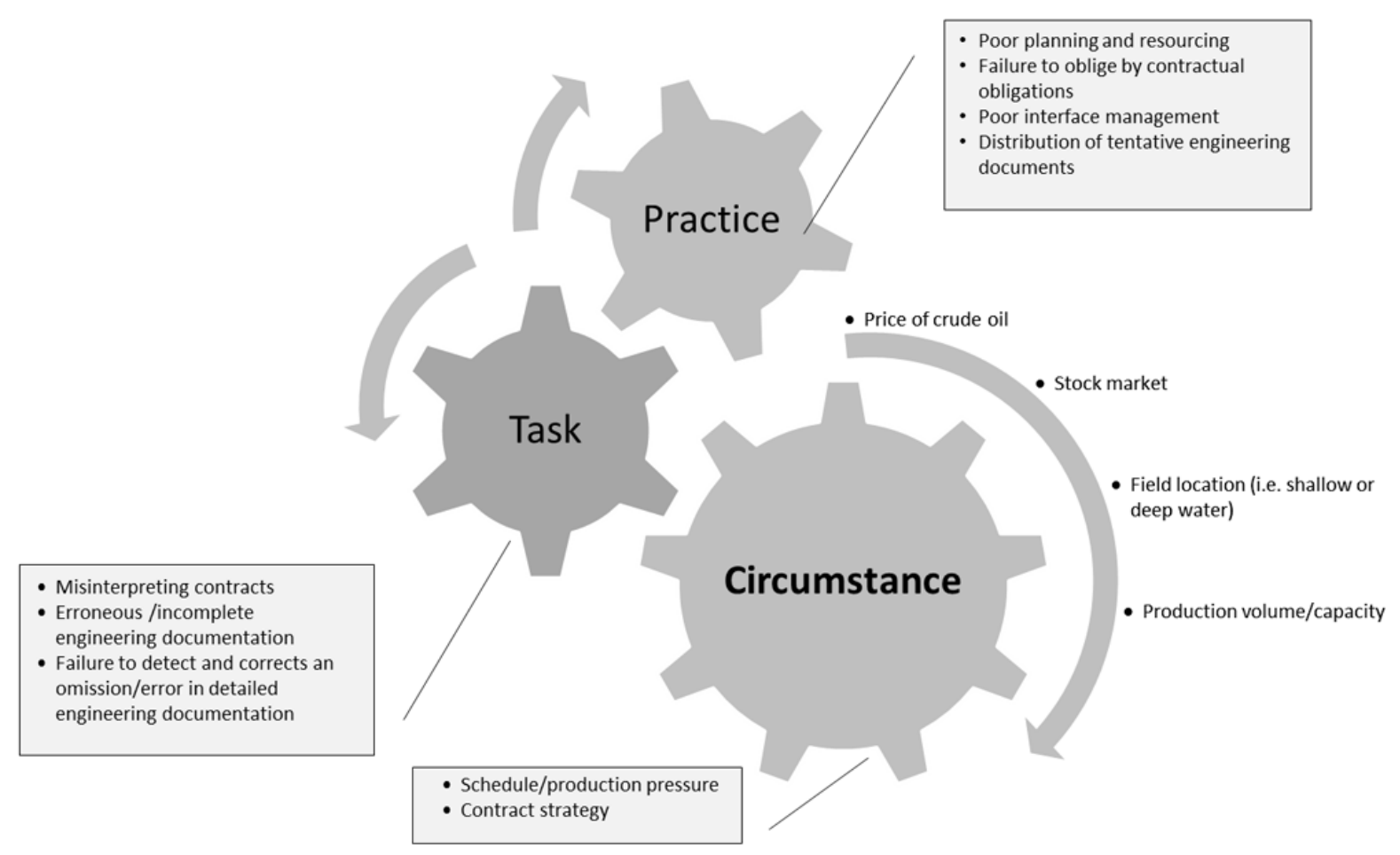

Fig. 4. Interrelationship between pathogens 
Table 3. FPSO project details

\begin{tabular}{ccccccc}
\hline Projects & $\begin{array}{c}\text { Examples } \\
(\mathrm{N})\end{array}$ & $\begin{array}{c}\text { CAPEX } \\
(\mathrm{A} \$ \mathrm{~m})\end{array}$ & $\begin{array}{c}\text { Duration* } \\
(\text { weeks })\end{array}$ & $\begin{array}{c}\text { Cost overrun } \\
(\mathrm{A} \$ \mathrm{~m})\end{array}$ & $\begin{array}{c}\text { Schedule overrun } \\
(\text { weeks })\end{array}$ & $\begin{array}{c}\text { Rework }(\$) \\
(\% \mathrm{CAPEX})\end{array}$ \\
\hline Conversion & 2 & $\approx 800$ & 130 & - & - & $\approx 55^{* *}$ \\
New Build & 3 & $\approx 600$ & 104 & 130 & 10 & $\approx 10$ to 15 \\
\hline
\end{tabular}

* Duration refers to the construction period and excludes feasibility, engineering design and procurement.

** Rework occurred during production after the project was completed (Total estimated cost $\approx \mathrm{A} \$ 500 \mathrm{M}$ including indirect costs).

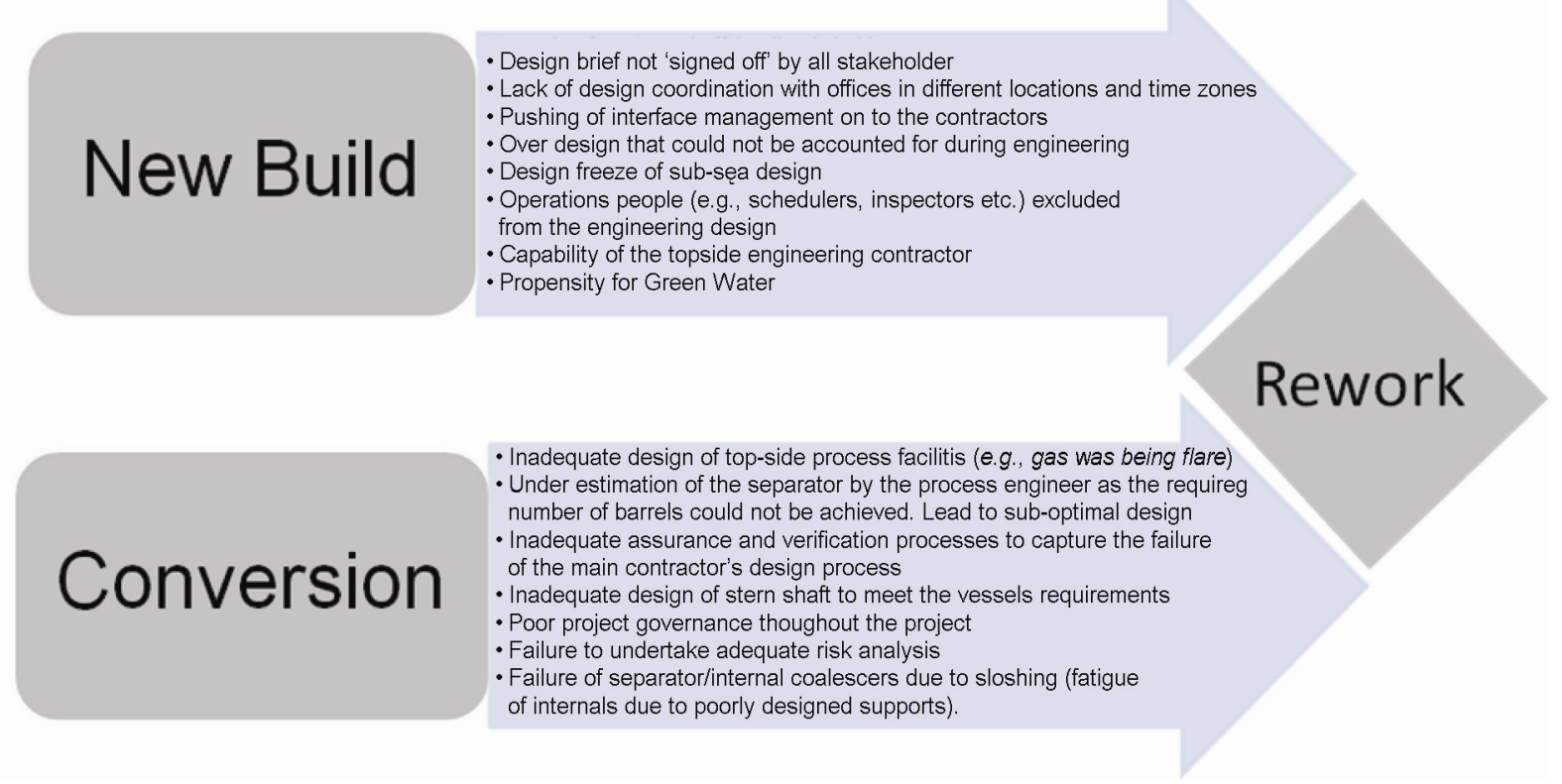

Fig. 5. Key factors contributing to rework for new build and conversion FPSOs

\section{Conversion and new build FPSO: vignettes of experience}

Several of the issues identified in Table 2 are contextualized using vignettes for a conversion and new build FPSO. The vignettes present an interpretation of several core rework issues that arose. The meaning and existence of rework is unequivocal; this critical issue must be addressed to reduce cost and schedule growth as well as improve FPSOs' operational performance. As noted in Table 3, rework costs of $55 \%$ and 10 to $15 \%$ of CAPEX for the conversion and new build FPSOs respectively, were reported. Noteworthy, research has revealed that FPSOs that experienced significant cost and schedule growth perform better than expected during operations, as their final quality exceeded the original specification (Llewellyn 2011). In Figure 5, issues identified as contributing to rework for the conversion and new build FPSO are summarized.

\subsection{Conversion FPSO}

A hydrocarbon reservoir had been identified but despite extensive computer simulation and modelling, a degree of uncertainty remained about its size and the quantity of crude oil to be extracted. Despite the reservoir's uncertainty, and having already committed more than A $\$ 100$ million the recommendation was made to proceed with the project. The most viable and economic option to extract the hydrocarbon was identified as being an FPSO. The subsea system (which included elements such as Christmas Trees, Control Systems and Subsea Distribution Unit) was designed and constructed by an engineering and construction contractor. A twenty-five year old oil tanker was purchased for US\$20 million from a shipping company to convert into an FPSO; a so-called 'brown field revamp'. A contractor designed and constructed the topside facilities, the hull was modified in a dry dock and the oil company undertook the responsibility for topside integration. The FPSO was designed to produce 115,000 barrels of oil per day $(\mathrm{Bo} / \mathrm{pd})$. The vessel was delivered on time and on budget to site but during operation latent errors began to emerge. Within two weeks of arriving on-site the vessel's cables and risers were functioning and producing oil but less than $65,000 \mathrm{Bo} / \mathrm{pd}$ of the expected rate was being produced with significant gas flare occurring. With any future production increase, gas flare would have also increased thus exceeding the company's regulations and the environmental policies (to reduce greenhouse gas emissions) contained within their operating license. The excessive gas flare was caused by incorrect design of the topside process facilities but once it was contained, production subsequently reduced. 
During conversion, the contractor decided not to replace the stern bearings, despite their short-life expectancy, they were deemed capable of undertaking required tasks. However, within the first few months on-site, the stern shaft that had not been re-designed failed as a result of the contractor's failure to adequately engineer for the FPSO's harsh operational environment. The propeller and its components were adequate for covering long distances at a constant speed (i.e. trailing tanker mode) but not for slower speeds and idling for considerable periods of time while connected to the turret and mooring system. The FPSO's engines are placed in idle mode to prevent it from colliding with the mooring system. When the FPSO is subjected to inclement weather (e.g. cyclonic conditions) it can be disconnected and sail away. A cyclone was forecast; the FPSO disconnected and began to move out of its path. The propeller shaft seized because it had been sitting in an idle mode and it had not received adequate lubrication, which in turn lead to seal and bearings failure. An operations manager stated:

"This would have been easy to fix during the conversion as it was in a dry dock. It was overlooked. It may have cost more to install new bearings but now it's going to cost even more to rectify. I guess rework in our industry is not cheap. It is serious dollars."

While the contractor overlooked replacing the seal and bearings, a project manager stated: “...if we'd have undertaken adequate risk analysis we'd have spotted the propeller fault."

Tugs were required to take the FPSO to a dry dock located thousands of kilometres from the oil field. Lost production was experienced and a dry dock had to be booked at considerable expense. The FPSO was redundant for approximately four months. After two years of producing oil at a reduced rate, the bottleneck that was inhibiting production was identified and the FPSO removed off-site again to a dry dock to be rectified. In addition, the separator and internal coalescers failed due to sloshing, yet suppliers did not understand the loads associated with the separators. The FPSO was off-site for six months while it was debottlenecked and it was estimated that the costs of inspection and rectification were approximately A $\$ 300$ million. The FPSO's topside design was significantly modified (e.g. new gas turbines) and when returned to site, the overhauled vessel could produce 135,000 to $140,000 \mathrm{Bo} / \mathrm{pd}$ as opposed to the original requirement of 115,000 Bo/pd. Debottlenecking the topside cost an estimated A\$200 million of CAPEX excluding the cost of lost production. The topside was unable to function as originally required and had simply not been designed to produce the required $115,000 \mathrm{Bo} / \mathrm{pd}$. The main separator had been incorrectly designed by the contractor's process engineer and thus an engineering manager stated that:

"This was our first FPSO, and it's been a steep learning curve. But in essence, I guess our assurance and verification processes didn't capture the failure of the main contractor's design process. Rework was problematic - it was a totally unique experience for us and I guess for the contractor. Poor design, poor decision-making, and initial schedule and cost constraints provided a breeding ground for something to go seriously wrong."

Being the oil company's first FPSO, considerable lessons were learned and all interviewees acknowledged that their own quality assurance and quality controls needed more stringent adherence. Emphasis needed to be placed on project governance and risk management. The increasing use of a Front End Loading ${ }^{2}$ index goes some way to addressing this issue but in the future the oil company will procure new FPSOs rather than refurbished tankers.

\subsection{New build FPSO}

In this next example, a new build FPSO was procured as the most economical option for extracting oil. The oil company had learnt from its previous experience, particularly with the unnecessary losses in production and profit arising from using a converted tanker. Nevertheless a series of different causal factors contributed to rework during the project's execution and operation (Table 3). The new build FPSO was ordered to operate in deep water (>350 metres) with a disconnectable double-skinned hull to comply with the International Convention for the Prevention of Pollution from Ships. The FPSO was designed to produce $\leq 100,000 \mathrm{Bo} / \mathrm{pd}$ and store approximately $900,000 \mathrm{Bo} /$ pd at any point in time. It had five oil production wells, six water re-injection wells and two gas injection wells. During normal operations, oil, water and gas are extracted from beneath the seabed and piped to the FPSO for separation and treatment. Gas and water are reinjected into the reservoir for environmental reasons whilst oil is stored in cargo tanks, located inside the vessel's double hull. It is anticipated that the vessel will be located on-site for more than 10 years. During the design process issues associated with the number of drill centres required had not been clarified by the operator to the engineering team. Determination of the hydrocarbon reservoir capacity (e.g. average permeability, and composition of hydrocarbons) had not been finalised by the operator, despite extensive use of simulation and threedimensional (3-D) modelling. A project manager stated:

"Obtaining knowledge about an underground reservoir costs time and money. It is a balance to obtain sufficient understanding of the next project's development phase and trying to reduce time to get better results from the economical analysis, a process of uncertainty reduction and a process of opportunities through 3-D tools. It's all a matter of risk; you can't be $100 \%$ certain what a reservoir will produce. In all honesty, we weren't certain."

Increasing shareholder confidence in the project was pivotal, so a decision to progress to the design phases was undertaken, despite the uncertainty that prevailed and the

\footnotetext{
${ }^{2}$ Key input parameters to determine a FEL index include: quality of engineering and scope definition, quality of cost and schedule estimates, maturity of project management system and procedures, quality of project execution plan (e.g. contracting strategy, quality management system, risk management, etc.), organisational structure, involvement of construction and operations personnel, and stakeholder plans.
} 
design brief not being signed off by all stakeholders. Data obtained from the subsurface was submitted to the facilities engineer to develop the project's specification, which was then used to procure an FPSO. A single firm was awarded the contract for the design and the construction of the vessel, however, a different firm was awarded the topside facility contract. The design engineers were unsure of the number of risers and umbilicals that would be required to interface with the drill centres. Without first consulting the oil company, the engineers proceeded to design the FPSO purely based upon the initial specification and their experience. Work had commenced at the subsea level to determine the number of oil production wells and establish the field layout requirements (e.g. Christmas Trees and Manifolds). Work was suspended due to the uncertainty associated with the oil reservoir; a design freeze occurred. Computer simulation and modelling of the field was completed and a degree of confidence was obtained regarding the production capacity that could be attained. The subsea layout required rectification, which resulted in rework occurring. This rework created changes to the FPSO design which subsequently delayed the FPSO and placed contractors under pressure to accelerate works. In addressing the schedule pressure, the design engineers failed to undertake adequate design reviews and checks as part of its quality assurance system. Errors in the hull and topside design emerged. The hull's structural integrity was questionable and fears grew that any instability would significantly influence the propensity for green water loading to occur. This design error was not identified until the vessel was being constructed in its dry dock. Engineering was being undertaken in two locations: the Northern and Southern Hemispheres. To expedite the design schedule, the engineering and construction firm utilised the design team's office from two separate time zones. Each day, as one team finished, unfinished tasks were handed over to another team to progress. The vessel's construction team had two different points of reference to seek clarification about engineering queries. Communication between the engineering and construction teams within the same firm was limited and the need to integrate works with the topside contractor further exacerbated this problem.

A gantry crane was needed to rectify the stability issue identified. However, it was not available in the shipyard as it had been pre-booked for use on other vessels. A project manager stated:

"If a crane was not available then it would have delayed us even more. We were on a tight schedule. What was more concerning was that we could only be in the dry dock for a fixed period of time. Other vessels were planned to come in. If the fit-out was not to be completed in a dry dock then it would have to be done over water now this is also expensive, about $A \$ 100$ to $A \$ 200 \mathrm{k}$ per day for an additional crane. Errors in logistics can be punishing and the stress was unbearable."

Another problem that emanated pertained to the air conditioned $(\mathrm{A} / \mathrm{C})$ accommodation on the FPSO; it had been designed for FPSOs operating in the Northern Hem- isphere rather than in the Southern Hemisphere where the climate is far hotter and humid. This design error only became evident when the FPSO had commenced operations on-site. It was perceived that this design error could have been prevented if design checks and coordination with the topside contractor had been undertaken.

\section{Learning from experience(s)}

Understanding the organizational and project context within which FPSOs are procured is pivotal to error reduction and containment. The rework causes identified from the analysis of interviews were generally systemic in nature, a finding which has also been identified in previous studies that have examined errors in industries such as mining (Goh et al. 2012), nuclear (UK Atomic Energy Authority 1987), and shipping (Wagenaar, Groeneweg 1987) Strategic decisions, such as the choice of contract strategy and schedule optimism arising from production pressure, laid the foundations for deviations from practice, policy and process to materialize during construction and operations. Nonetheless, a dichotomy existed between the 'individual' and 'organization' in relation to rework. Informally, individual employees knew and even expected rework to occur but the organizational rhetoric denied its existence. In fact, many organizations that were approached to participate in this study were reluctant to openly share their knowledge and experiences of rework within FPSOs.

The Norwegian Oil Industry Association's ${ }^{3}$ (OLF) 'FPSO and ST Workgroup', and FPSO Research Forum ${ }^{4}$ have, however, been proactive in establishing $\mathrm{CoP}$ whereby lessons learnt about FPSO experiences are transferred and shared. Indeed, these aforementioned experiences, combined with those from United Kingdom, have identified many design and construction errors that have adversely influenced FPSOs' operational performance in the field. A UK report on the causes of FPSO errors went further by identifying technical specification in addition to the contract strategy adopted (e.g. interface management) (Llewellyn et al. 2002).

Learning about rework causation through interaction and participation with professionals associated with FPSOs is an effective learning milieu for its reduction. CoP such as the FPSO Research Forum can help to formalize situated knowledge and learning, although the extent to which it learns internally or imports new knowledge is in part a function of the nature of the practices it undertakes (Wenger et al. 2002). The situated dimensions of learning are concerned with its practical and social aspects within a context. Most people learn on the job in culturally embedded ways. This learning evolves through participation and interaction of people and their collective sense-making activities as they develop competencies and construct their identities to function effectively. Interaction is therefore a prerequisite for learning how to prevent errors as it facilitates the sharing of experiences. This situated perspective may encourage

\footnotetext{
${ }^{3} \mathrm{http}: / /$ fpso.olf.no

${ }^{4} \mathrm{http}: / /$ www.fpsoforum.com
} 
oil companies, operators, contractors and the like, to undertake project-based learning and interaction so as to make 'sense' of their activities. Such learning should be undertaken at an organizational level as individuals may not automatically learn from their own experience. In order to learn, individuals need to test new experiences against existing knowledge and then consciously reflect upon what has transpired (Busby 1999). The accumulation of 'collective knowledge' is an enabler to systemic intervention by changing the conditions under which the individuals performs their tasks, so that design errors are reduced or eliminated in future projects.

Some underlying issues can be derived from the rework experience(s) that have been collated. Senior management decisions are often influenced by environmental demands imposed upon them which in turn, influence the project's resourcing capacity and the extent that policies and procedures are adhered too. Each participating organization has differing goals, objectives and learning capacity which may further compound embedded problems within project systems and processes. The project's contracting strategy must, therefore, ensure that goal alignment is ensured. The EPC contracting strategy severely inhibits goal alignment between participating project organizations, especially when competitive price determination becomes a driver for service selection. Instead alliances with an inbuilt learning capability and performance incentives could be used to establish a proactive project culture that drives the behaviour of organizations to achieve successful project outcomes and reduce rework. The specific inclusion of key contractors and operations personnel into the design and engineering process is critical for determining a realistic schedule, interfaces, and minimizing design and construction errors. Such an alliance may comprise of a competitive consortium of contractors who propose a FPSO design solution for a pre-determined fee, and if successful, negotiate a contract price with the oil company. Specific details of how alliance contracts, based upon risk/reward compensation models, have been used to successfully procure large-scale engineering projects can be found in Love et al. (2011b).

Implementing strategies to increase production capacity, profit and 'share price' by unnecessarily accelerating activities can lead to rework, jeopardize safety and the environment. This strategic risk can cause a significant 'ripple effect' throughout the owner and oil company's organization and other supply chain organizations which strive to meet the demands and constraints imposed upon them. Mismanagement, mostly people with no training in managing risks was identified as a basic condition contributing to the collapse of BP's Deepwater Horizon (Bea et al. 2010). There was an explicit expectation that BP should have learnt lessons from the incidents that occurred at its Grangemouth Complex in 2000 (HSE 2003), Texas City refinery accident in 2005 and the collapse of the Thunder Horse platform in the Gulf of Mexico in 2006 (Bea et al. 2010; Hopkins 2010). Lack of training, poor communication, poor supervision and fatigue have been identified as contributors to BP's accidents (Bea et al. 2010). These findings are not dissimilar in nature to those reported in this paper contributing to rework in FPSOs.

\section{Limitations}

Using interviews, the research sought to determine the latent conditions that contribute to rework in FPSO projects. This represented a challenging task due to the commercial sensitivity associated with this issue, which lead to some interviewees being reluctant to speak openly about specific events. This naturally brings forth several limitations as far as the reliability and generalizations of the research results are concerned.

When interviews of this nature reveal some of the complexities associated with delivering FPSOs, there often is a problem with representation. It is difficult to present accessible and realistic views of events that lead to rework occurring. For example, interviews were used to identify rework and obtain information about how and why they occurred. Thus there was a potential for interviewees to intentionally or unintentionally conceal information. Moreover, there are often several different ways to present the same set of issues, each one of which is subtly different in its approach and emphasis. This situation can make the findings derived from interviews difficult to summarize and thus contribute to the occurrence of situational biases.

Another limitation of this research is the adopted perspective. Instead of trying to understand how and why strategic decisions are generally made within projects, this research has been first and foremost limited to an operational focus. Although the research has also taken into account an array of views along the development of its theoretical analysis, the main perspective from which conclusions have been drawn are from those who were generally operating at the 'coalface' within the projects sampled. Understanding the rationale for key strategic decisions adopted by oil and gas companies would have undoubtedly provided a more fruitful and comprehensive understanding of the pathogenic influences contributing to rework. Building upon the research presented in this paper and the normative literature, it is suggested that additional descriptive case studies based research should be undertaken to further derive the conditions for quantitative studies to assess the probability of rework.

\section{Conclusions}

Clarifying the causal nature of rework in FPSO projects has been the main emphasis of the research presented in this paper. Practitioners' rework experiences were solicited and categorized according to the nomenclature of people, organization and project. The key factors associated with the 'project' were the pressure to commence production and inadequate interface management. In particular, inadequate interface management is an area that has been repeatedly identified as being problematic within FPSO projects. The use of specialist interface contractors has begun to proliferate in recent years. However, such a role simply adds another layer to an already highly differentiated process of delivery for FPSOs. Utilizing an integrat- 
ed learning alliance with inbuilt contractual incentives may present a viable alternative contract strategy that oil companies could consider for future FPSO projects. As a result, this would provide a mechanism for stimulating the input of construction contractors and operations personnel into FEED.

Under the nomenclature of 'organization' the distribution of tentative engineering documents and unrealistic schedules were identified as key contributors of rework. In this instance, the interrelationship between these variables is evident; schedule pressure can lead to shortcuts or oversight taking place. With respect to 'people', stress due to workload arose because of schedule pressure, although the industry's prevailing skills shortage has contributed to longer work hours for staff who strive to complete tasks. While the lack of labour supply was not mentioned in the interviews, it is an exogenous variable that is adversely impacting the industry's productivity. The pathogen of 'circumstance' stimulated the occurrence of influencing 'task' and 'practice' actions. For example, whilst competitive tendering may encourage lowest cost selection, it increases the likelihood that tasks and processes are not completely effectively thus providing a ripe environment for error propagation.

The vignettes provide an insight into the experience of several specific errors that arose in a conversion and new build FPSO. Learning from experience(s) is necessary to reduce rework in FPSO projects. The use of CoP provides a forum for situated learning to occur but the challenge is to ensure that learning is translated into practice. Formally recognizing that rework is a problematic issue that needs to be measured and managed presents an ongoing challenge for all parties involved in the engineering, construction, installation and operation of FPSOs. There is a caveat to the research work undertaken and reported upon here. There is the potential for bias in the experiences that were accumulated from the vignettes that were presented, as only the perspectives of the oil company were gathered. Moreover, the rework costs were 'estimates' based upon intuition, as it was formally measured. In addition, a systemic approach to rework was undertaken and, therefore, the technical nuances of the FPSOs have not been considered. Needless to say, the research has identified an area that has received limited attention. More fundamental research and discussions with industry professionals in the future is required to obtain a richer contextual backdrop about rework causes and the consequences of rework so that effective mitigation strategies can be developed.

\section{Acknowledgements}

The authors would like to thank the anonymous reviewers, Professor Jim Smith and Dr Sangwon Han for their constructive comments that have helped improve the quality of this manuscript. The authors would like to acknowledge the financial support provided by the Australian Research Council (DP 0453258). The authors would also like to thank the interviewees who participated in this research project.

\section{References}

Alford, G. 1997. FPSO classification, Offshore October: 8-18.

Alvesson, M.; Deetz, S. 1996. Critical theory and postmodernism approaches to organizational studies, in Clegg, A. R.; Hardy, C.; Nord, W. R. (Eds.). Handbook of Organization Studies. London: Sage Publications, 191-217.

Bantz, C. R.; Smith, D. H. 1977. A critique and experimental test of Weick's model of organizing, Communication Monographs 44(3): 177-184.

http://dx.doi.org/10.1080/03637757709390129

Bea, R. G.; Roberts, K.; Azwell, T.; Gale, W. 2010. Deepwater Horizon Study Group. Center for Catastrophic Risk Management, University of California, Berkeley, $15^{\text {th }}$ July 2010, Progress Report 2 [online], [cited 24 March 2011]. Available from Internet: www.ce.berkeley.edu

Berends, K. 2007. Engineering and construction projects for oil and gas processing facilities: contracting, uncertainty and the economics of information, Energy Policy 35(8): 42604270. http://dx.doi.org/10.1016/j.enpol.2007.02.027

Biasotto, P.; Rouhan, A. 2004. Survey and inspection management of FPSO, in Proceedings of the OMAE, $23^{\text {rd }}$ International Conference on Offshore Mechanics and Arctic Engineering, 20-25 June, 2004, Vancouver, British Columbia, Canada.

Brown, A. 2000. Make sense of inquiry sensemaking, Journal of Management Studies 37: 45-75.

Brown, R. 2004. FPSO: lessons learned, IEEE Industry Applications Magazine 10(2): 18-23. http://dx.doi.org/10.1109/MIA.2004.1270797

Busby, J. S. 1999. The problem with design reuse: an investigation into outcomes and antecedents, Journal of Engineering Design 10(3): 277-296. http://dx.doi.org/10.1080/095448299261335

Busby, J. S.; Hughes, E. J. 2004. Projects, pathogens, and incubation periods, International Journal of Project Management 22(5): 425-434.

http://dx.doi.org/10.1016/j.ijproman.2003.09.002

Cecil, W. 2008. Coordinate FPSO project contracts, E\&P Magazine, $20^{\text {th }}$ April [online], [cited 17 March 2011]. Available from Internet: www.epmag.com/magazine/2008

Diekmann, J. R. 2010. Was the BP explosion and accident or?, Renew America [online], [cited 17 March 2011]. Available from Internet:

www.renewamerica.com/columns/dieckmann

Eriksen, R. 2010. Industry must manage risk to control costs, Offshore, $3^{\text {rd }}$ June 2010 [online], [cited 23 November 2011]. Available from Internet: www.offshore-mag.com

Farrell, F. B. 1996. Subjectivity, realism, and postmodernism: the recovery of the world in recent philosophy. Cambridge: Cambridge University Press. 290 p.

Fischoff, B. 1975. Hindsight does not equal foresight: the effect of outcome knowledge on judgment under uncertainty, Journal of Experimental Psychology: Human Performance and Perception 1: 288-299.

Friedrich, D. R.; Daly, J. P.; Dick, W. G. 1987. Revisions, repairs, and rework on large projects, ASCE Journal of Construction Engineering and Management 113(3): 488500. http://dx.doi.org/10.1061/(ASCE)07339364(1987)113:3(488)

Fuglerud, G. 2010. RISKEX TM: the art of taking risks responsibly. Det Norske Veritas $29^{\text {th }}$ September [online], [cited 17 March 2011]. Available from Internet: http://www.marinemoney.com/forums 
Goh, Y.; Love, P. E. D.; Spickett, J.; Brown, H. 2012. Organizational accidents: a systemic model of production versus protection, Journal of Management Studies 49(1): 52-76. http://dx.doi.org/10.1111/j.1467-6486.2010.00959.x

Green, J. M. 1999. Lessons learned from the Schiehallion FPSO's design and construction, in Offshore Technology Conference, 1091-MS, 3-6 May, 1999, Houston, Texas.

Hardie, N.; Knowles, N. 2000. FPSOs - lesson learned. Offshore Technology Report, Health and Safety Executive, Project No. 3741, Prepared by IGL Engineering Ltd, July, London, UK

Harris, C. T.; Formigli, B.; Crager, S.; Eggen, S.; Reed, J.; Khurana, S. 2004. Commercial/contracting strategies for offshore projects, in Offshore Technology Conference, OTC 16680, 5-8 May, 2004, Houston, Texas, USA,

Hartshorne, C. 1962. Mind as memory and creative love, in Scher, J. M. (Ed.). Theories of the mind. New York: Free Press, 440-463.

Health and Safety Executive (HSE). 2003. Major incident investigation report BP Grangemouth, in Scotland $29^{\text {th }}$ May $10^{\text {th }}$ June. A Public Report Prepared by the HSE on Behalf of the Competent Authority, HSE, London, UK.

Hopkins, A. 2010. Failure to learn: the BP Texas City refinery disaster. $\mathrm{CCH}$, Australia Limited.

House, J. D. 2002. Myths and realities: about petroleum-related development: lessons for British Columbia from Atlantic Canada and the North Sea, Journal of Canadian Studies 37(4): 9-32.

Hwang B.-G.; Thomas, S. R.; Haas, C. T.; Caldas, H. 2009. Measuring the impacts of rework on construction cost performance by project characteristics and sources of rework, ASCE Journal of Construction Engineering and Management 135(3): 187-198.

http://dx.doi.org/10.1061/(ASCE)07339364(2009)135:3(187)

James, W. 1950. The Principles of Psychology. Vol. 1 and 2, Dover, NY. Cited in Weick, K. E. 1995. Sensemaking in Organizations. Thousand Oaks: Sage Publications. 24 p.

Kim, M. 2002. Non-western perspectives on human communication: implications for theory and practice. Thousand Oaks: Sage Publications. 248 p.

Kvale, S. 1996. Interviews: an introduction to qualitative research interviewing. Thousand Oaks: Sage. 326 p.

Langer, E. J. 1975. The illusion of control, Journal of Personality and Social Psychology 7: 185-207.

Le Cotty, A. 2003. New build generic large FPSO, in Offshore Technology Conference, OTC 15311, 5-8 May, 2003, Houston, Texas, USA.

Llewellyn, D. 2011. 10 year operability survey of Norwegian FPSOs, in A Report Prepared for the Norwegian Oil Industry Association, OLF by the Offshore Management Centre, Aberdeen, $15^{\text {th }}$ March [online], [cited 20 March 2011]. Available from Internet: www.fpso.olf

Llewellyn, D.; Capsey, M.; Dyrkoren, E. 2002. FPSO lessons learned, in A Report Prepared for the Norwegian Oil Industry Association, OLF by the Offshore Management Centre, Robert Gordons University, Aberdeen, $20^{\text {th }}$ September [online], [cited 20 March 2011]. Available from Internet: www.fpso.olf

Lloyd's Register. 2003. FPSO inspection repair and maintenance: study into best practice. Lloyd's Register of Shipping, R20281-UKOOA, $6^{\text {th }}$ May [online], [cited 17 March 2011]. Available from Internet: www.oilandgasuk.co.uk
Lombardo, L. 2003. Overview of floating production, storage and offtake (FPSO) service agreements, Australian Resources and Energy Law Journal 22: 468-484 [online], [cited 17 March 2011]. Available from Internet: www.austlii.edu.au/au/journals/AURELawJl/2003/104.pdf

Lopez-Cortijo, J.; Duggal, A.; Matos, R.; Van Dijk, R. 2003. Design aspects of a DP system for FPSO applications in GOM. Session for 'FPSOs and Shuttle Tankers', in $D y$ namic Positioning Conference, 16-17 September, 2003, 1-17 [online], [cited 18 March 2011]. Available from Internet: www.dynamic-positioning.com

Love, P. E. D. 2002. Influence of project type and procurement method on rework costs in building construction projects, ASCE Journal of Construction Engineering and Management 128(1): 18-29. (ASCE)0733-9364(2002)128:1(18)

Love, P. E. D.; Edwards, D. J. 2013. Curbing rework in offshore projects: systemic classification of risks with dialogue and narratives, Structure and Infrastructure Engineering 9(11): 1118-1135.

Love, P. E. D.; Edwards, D. J.; Irani, Z.; Walker, D. H. T. 2009. Project pathogens: the anatomy of omission errors in construction and resource engineering projects, IEEE Transactions on Engineering Management 56(3): 425-435. http://dx.doi.org/10.1109/TEM.2008.927774

Love, P. E. D.; Davis, P. R.; Chevis, R. 2011b. Risk/reward compensation models in alliances for the delivery of civil engineering infrastructure projects, $A S C E$ Journal of Construction Engineering and Management 137(2): 127-136. http://dx.doi.org/10.1061/ (ASCE)CO.1943-7862.0000263

Love, P. E. D.; Edwards, D. J.; Irani, Z.; Goh, Y. M. 2011 a. Dynamics of rework in complex hydrocarbon offshore structures, ASCE Journal of Construction, Engineering and Management 137(12): 1060-1070.

http://dx.doi.org/10.1061/(ASCE)CO.1943-7862.0000377

Love, P. E. D.; Holt, G. D.; Li, H. 2002. Triangulation in construction management research, Engineering, Construction and Architectural Management 9(4): 294-303. http://dx.doi.org/10.1108/eb021224

Love, P. E. D.; Irani, Z.; Edwards, D. J. 2004. A rework reduction model for construction projects, IEEE Transactions on Engineering Management 51(4): 426-440. http://dx.doi.org/10.1109/TEM.2004.835092

Marin, B. B.; Garcia, J. L.-C. 2003. Design aspects of green water loading on FPSOs, in Proceedings of the $22^{\text {nd }}$ International Conference on Offshore Mechanics and Arctic Engineering, 8-13 June, 2003, Cancun, Mexico.

McConnell, S. 1999. Brooks' law repealed, IEEE Software 16(6): 6-8. http://dx.doi.org/10.1109/MS.1999.754046

Merrow, E. W. 2003a. Taking on the cult of mediocrity, Upstream $23^{\text {rd }}$ May, 28-29.

Merrow, E. W. 2003b. Mega-field developments require special tactics, risk management. Independent project analysis [online], [cited 20 March 2011]. Available from Internet: http://www.ipainstitute.com

Moan, T.; Amdahl, J.; Wang, X.; Spencer, J. 2002. Risk assessment of FPSOs, with emphasis on collision, in $A B S$ Technical Paper, Offshore Technology Conference Houston, 6-9 May, Texas, U.S.A., 199-229.

Mueller, W.; Roobaert, N. 2008. Standardization adds value to FPSO topsides. Offshore, $1^{\text {st }}$ March, 68(3) [online], [cited 17 March 2011]. Available from Internet: www.offshore-mag.com 
Nam, K.; Chang, D.; Chang, K.; Rhee, T.; Lee, I. 2011. Methodology of life cycle cost and risk expenditure for offshore process at conceptual design stage, Energy 36(3): 1554-1563.

http://dx.doi.org/10.1016/j.energy.2011.01.005

Paté-Cornell, M. E. 1990. Organizational aspects of engineering system reliability: the case of offshore platforms, Science 250(4985): $1210-1217$.

http://dx.doi.org/10.1126/science.250.4985.1210

Performance Forum. 2000. Final Report on FPSO Cost and Schedule Performance Study Phase 1. Issue 1, Pace Project Services, Edinburgh, UK.

Reason, J. T. 1990. Human error. Cambridge: Cambridge University Press. $302 \mathrm{p}$. http://dx.doi.org/10.1017/CBO9781139062367

Reason, J. T. 1997. Managing the risks of organizational accidents. Farnham: Ashgate. $252 \mathrm{p}$.

Ren, J.; Jenkinson, I.; Wang, J.; Xu, D. L.; Yang, J. B. 2008. A methodology to model causal relationships on offshore safety assessment focusing on human and organizational factors, Journal of Safety Research 39(1): 87-100. http://dx.doi.org/10.1016/j.jsr.2007.09.009

Roberts, K. H.; Bea, R. G. 2001. Whey systems fail, Organizational Dynamics 29(3): 179-191. http://dx.doi.org/10.1016/S0090-2616(01)00025-0

Saleh, J. H.; Marais, K. B.; Bakolas, E.; Cowlagi, R. V. 2010. Highlights from the literature on accident causation and system safety: review of major ideas, recent contributions and challenges, Reliability Engineering and System Safety 95(11): 1105-1116.

http://dx.doi.org/10.1016/j.ress.2010.07.004
Schutz, A. 1967. The phenomenology of the social world. Illinois: Northwestern University Press. 255 p.

Shin, H. S.; Sim, W. S.; Moon, J. S.; Yoon, K. Y. 2008. Collaboration for EPC of offshore structures, in Offshore Technology Conference, OTC 19696, 5-8 May, 2008, Houston Texas, USA.

UK Atomic Energy Authority. 1987. The Chernobyl Accident and its Consequences. London: HMSO.

Vinnem, J. E. 2000. Operational safety of FPSOs: initial summary report. Norwegian University of Science and Technology, Faculty of Marine Technology, Bryne Norway, prepared for the Health and Safety Executive, HMSO, Norwich, UK.

Wagenaar, W. A.; Groeneweg, J. 1987. Accidents at sea: multiple causes and impossible consequences, International Journal of Man-Machine Studies 27(5-6): 587-598. http://dx.doi.org/10.1016/S0020-7373(87)80017-2

Wang, G.; Jiang, D.; Shin, Y. 2003. Consideration of collision and contract damage risks in FPSO structural designs, in ABS Technical Paper, Offshore Technology Conference Houston, 5-8 May, 2003 Texas, U.S.A., 199-229.

Weick, K. E. 1988. Enacted sensemaking in crisis situations, Journal of Management Studies 25(4): 305-317. http://dx.doi.org/10.1111/j.1467-6486.1988.tb00039.x

Weick, K. E. 1995. Sensemaking in organizations. Thousand Oaks: Sage Publications. 231 p.

Weick, K. E.; Sutcliffe, K. M.; Obstfeld, D. 2005. Organizing and the process of sensemaking, Organization Science 16(4): 409-421. http://dx.doi.org/10.1287/orsc.1050.0133

Wenger, E.; McDermott, R.; Synder, W. M. 2002. Cultivating communities of practice: a guide to managing knowledge. Harvard Business School.

Peter E. D. LOVE. He is a John Curtin Distinguished Professor at Curtin University. He is a Fellow of the Royal Institute of Chartered Surveyors (FRICS) and was the inaugural recipient of 2010 Scopus Young Australian Researcher of the Year Award (Humanities and Social Science) and a member of the Australian Research Council's Engineering and Environmental Science Panel for the 2010/11 Excellence in Australian Research Exercise. He currently has co-authored/edited six books and has authored/co-authored over 500 internationally refereed research papers, which have appeared in leading international journals. His research interests include BIM, systems safety, and operations and production management.

David John EDWARDS. He is the founder of OPERC, the Hand-Arm Vibration Test Centre (HAVTEC) and is currently Head of Faculty Research at Birmingham City Business School, Birmingham City University. He also established the Plant and Equipment Professional trade magazine and the annual Plant and Equipment Management Innovation Conference event. He is a leading academic in the field of Plant and Machinery Management and has attracted several millions of research funding from industry during his career as well as publishes textbooks, conference papers and over 150 peer referee research papers and act as peer referee for over 30 scientific journals. His work into Hand-arm Vibration Management recently won a medal from the United States Dept. of Defense and he continues to be an active panellist on specialist Health and Safety Executive (HSE) consultative panels. He currently holds two visiting professorships at Curtin University, Western Australia and KNUST, Kumasi in Ghana. He has extensive collaborative links with practitioners within the plant hire, construction, warehouse and distribution, civil engineering and quarrying industries.

Zahir IRANI. He is the Head of Brunel Business School; he is an accomplished leader, researcher and thinker, and has given numerous press and thought leadership pieces on higher education and employability that have appeared in The Guardian, The Independent, The Wall Street Journal, Financial Times (FT), Thomson Reuters and Times Higher Education (THE). Under his leadership, Brunel Business School continues to feature in the prestigious Financial Times "European Business School Rankings", and has likewise achieved excellent levels of student satisfaction, at Undergraduate level, in the UK's "National Student Survey" (NSS). He has published over 400 internationally referred research papers, which have appeared in leading international journals.

Nuria FORCADA. She is a Lecturer in the Department of Construction Engineering at Universitat Politecnica de Catalunya (UPC). She is a member of the Group of Construction Research and Innovation (GRIC) that conducts interdisciplinary research to improve the productive processes of the construction sector companies. She received her PhD from the UPC and her research interests include Quality and defect management, Collaborative working environment, Knowledge Management, Decision Making Systems and e-learning. 